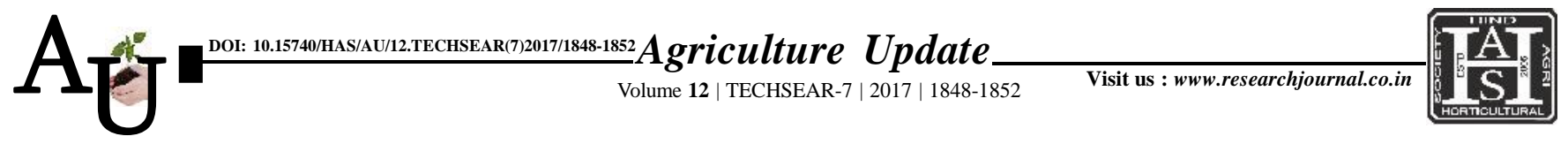

\title{
Research Article: Growth and yield of Rabi popcorn hybrid at varied plant densities and nitrogen levels
}

Y. SIVA LAKSHMI, D. SREELATHA AND T. PRADEEP

Article Chronicle:

Received :

19.07.2017;

Accepted :

03.08.2017

KEY WoRDS :

Popcorn, Rabi, Plant densities, Nitrogen

levels, Growth

parameters, Yield
SUMMARY : A field experiment was conducted during Rabi seasons of 2011-12 and 2012-13 at Maize Research Centre, ARI, Rajendranagar, Hyderabad to study the influence of varying plant densities and nitrogen levels on growth parameters and yield of BPCH-6, the first popcorn hybrid released by PJTSAU at national level. The experiment was laid out in Randomized Block Design with factorial concept with three plant densities $\left(\mathrm{P}_{1}-1,11,111 \mathrm{ha}^{-1}(60 \times 15 \mathrm{~cm}), \mathrm{P}_{2}-1,11,111 \mathrm{ha}^{-1}(45 \times 20 \mathrm{~cm})\right.$ and $\mathrm{P}_{3}-83,333 \mathrm{ha}^{-1}(60 \mathrm{x}$ $20 \mathrm{~cm})$ and four nitrogen levels $\left(\mathrm{N}_{1}-80 \mathrm{~kg} \mathrm{ha}^{-1}, \mathrm{~N}_{2}-120 \mathrm{~kg} \mathrm{ha}^{-1}, \mathrm{~N}_{3}-160 \mathrm{~kg} \mathrm{ha}^{-1}\right.$ and $\left.\mathrm{N}_{4}-200 \mathrm{~kg} \mathrm{ha}^{-1}\right)$ and replicated thrice. Mean data over 2 years indicated that plant height was significantly higher with high plant density of $1,11,111 \mathrm{ha}^{-1}(45 \times 20 \mathrm{~cm})$ and leaf area index was significantly higher with plant density of $1,11,111 \mathrm{ha}^{-1}(60 \times 15 \mathrm{~cm})$ whereas dry matter production $\left(\mathrm{g} \mathrm{plant}^{-1}\right)$ was significantly higher with $83,333 \mathrm{ha}^{-1}(60 \times 20 \mathrm{~cm})$. Cob, grain and fodder yields were significantly higher with a plant density of $1,11,111 \mathrm{ha}^{-1}(60 \times 15 \mathrm{~cm})$. Application of $200 \mathrm{~kg}$ nitrogen ha- ${ }^{-1}$ gave significantly higher growth parameters and yield but it was on par with $160 \mathrm{~kg} \mathrm{~N} \mathrm{ha}^{-1}$ and both were superior over 120 and $80 \mathrm{~kg} \mathrm{~N} \mathrm{ha}^{-1}$. Interaction effect of plant densities and nitrogen levels on grain yield showed that significantly higher grain yield $\left(6.0 \mathrm{t} \mathrm{ha}^{-1}\right)$ was obtained at a plant density of $1,11,111 \mathrm{ha}^{-1}(60 \mathrm{x} 15 \mathrm{~cm})$ with $200 \mathrm{~kg} \mathrm{~N} \mathrm{ha}^{-1}$ but it was on par with $160 \mathrm{~kg} \mathrm{~N}^{-1}$ with the same plant density.

How to cite this article : Lakshmi, Y. Siva, Sreelatha, D. and Pradeep, T. (2017). Growth and yield of Rabi popcorn hybrid at varied plant densities and nitrogen levels. Agric. Update, 12(TECHSEAR-7) : 1848-1852; DOI: 10.15740/HAS/AU/12.TECHSEAR(7)2017/1848-1852.
Author for correspondence :

\section{Y. SIVA LAKSHMI}

Department of

Agronomy, College of

Agricultural Engineering,

Kandi, SANGAREDDY

(TELANGANA) INDIA

Email : siva_yettapu@

rediffmail.com

See end of the article for

authors' affiliations 